DOI: 10.17951/lrp.2019.38.3.145-159

\author{
MirosŁaW MieczysŁaW WójCik \\ Państwowa Uczelnia im. Stefana Batorego w Skierniewicach, \\ Wydział Ekonomii i Administracji, Instytut Nauk Społecznych \\ ORCID - 0000-0002-9342-4106
}

\title{
REFLEKSJE PEDAGOGA NAD POTRZEBA DOSTRZEŻENIA ETYCZNYCH UWARUNKOWAŃ ZMIAN KONIECZNYCH W POSTAWACH NAUCZYCIELSKICH W XXI WIEKU CZĘŚĆ I (OD EDUKACJI NARODOWEJ DO EDUKACJI TRANSGRANICZNIE OTWARTEJ NA RÓWNOŚĆ W RÓŻNICACH)
}

\begin{abstract}
Streszczenie: $\mathrm{W}$ treści artykułu autor podejmuje próbę analizy współczesnych uwarunkowań koniecznych przemian w postawach nauczycielskich. Refleksję filozoficzną ukierunkowaną na etykę postrzega jako podstawę wyprowadzania wniosków co do optymalnego edukowania i kształtowania oraz zawodowego funkcjonowania osób odpowiedzialnych za wychowanie młodego pokolenia. W refleksyjności środowiska edukacyjnego postrzega też autor szansę na zrozumienie etycznych uwarunkowań przemian we współczesnych sylwetkach zawodowych nauczycielek i nauczycieli, które wymuszane są nowymi zjawiskami demograficznymi i społeczno-kulturowymi w Europie i na świecie. Artykuł wpisuje się w poszukiwania na wskroś nowoczesnego paradygmatu osobowościowego edukatorek i edukatorów w XXI wieku.
\end{abstract}

Słowa kluczowe: etyka, postawy nauczycielskie, przemiany cywilizacyjne, trans graniczna migracja ludności, równość w edukacji

\section{WPROWADZENIE}

Niniejsze opracowanie mieści się w gatunku i formie publicystyki pedagogicznej i wpisuje się nie tylko w naukowy, ale przede wszystkim w społeczny dyskurs nad potrzebami zmian w edukacji i przygotowaniem zawodowym współczesnych nauczycieli-wychowawców do pracy z dziećmi i młodzieżą. Na tej drodze koniecz- 
nych zmian edukacyjnych trzeba nowego, etycznego odniesienia dla pragmatyki pedagogicznej w dynamicznie zmieniającej się rzeczywistości Europy. Opracowanie składa się z dwóch części. W pierwszej części rozważania otwiera wątek dotyczący refleksyjnego i roztropnego uzasadnienia potrzeby zmian we współczesnych postawach nauczycielskich, co warunkowane jest transformacją cywilizacji trzeciego tysiąclecia. Przechodzi on $\mathrm{w}$ analizę aktualnego rozumienia postaw społecznych, w tym nauczycielskich, $\mathrm{z}$ odniesieniem do strukturalnej teorii postaw. W dalszej kolejności refleksja zmierza ku rozpoznaniu i zrozumieniu zmian koniecznych w postawach współczesnych nauczycieli ze względu na zjawisko transgranicznego przemieszczania się ludności oraz towarzyszące mu przenikanie się kultur, wyznań ras i nacji. Tę część rozważań zamyka analiza współczesnych postaw nauczycielskich powiązana $z$ ideą moralnego nakazu równego traktowania osób i grup społecznych w przestrzeni edukacyjnej.

\section{ZMIANY KONIECZNE W POSTAWACH NAUCZYCIELSKICH}

Aktualna rzeczywistość społeczno-edukacyjna w Europie i na świecie stawia przed koniecznością poszukiwania współczesnego modelu sylwetki zawodowej nauczyciela i wychowawcy (Barczyk 2003, s. 143-157). W utartych wzorcach i schematach warunkowanych tradycją i przyzwyczajeniami nie jesteśmy w stanie wyjść naprzeciw potrzebom cywilizacji XXI wieku (Suchocka, Królikowska 2014, s. 73-88). Mam na myśli nie tylko potrzeby w rozumieniu makro, oparte na głównych kierunkach rozwoju społeczeństw świata, ale także potrzeby w rozumieniu mikro, bo odnoszące się do mniejszych obszarów administracyjno-państwowych, które przecież pozostają jako państwa Europy i świata uczestnikami globalnych przemian. W takim znaczeniu przychodzi nam mierzyć się z nowymi wyzwaniami edukacji w Polsce - kraju pozostającego w synergii z procesami przemian Europy, a nawet świata (Dziewulak 1997, s. 9-18). Aktualne potrzeby zmian polskiej edukacji mogą być realizowane wyłącznie poprzez ewoluowanie postaw współczesnych polskich nauczycieli, ich mentalności, rozumienia świata współczesnego, otwartości na wszystko co nowe i będące wyznacznikiem rozwoju cywilizacyjnego w trzecim tysiącleciu (Dereń 2014, s. 173-227).

Świat współczesny pozostaje w opozycji do wzorców i modeli życia sprzed kilkudziesięciu, a nawet kilkunastu lat. Tempo zmian wydaje się tak duże, że owe zmiany dokonują się niejednokrotnie szybciej w sferze empirii społecznej niż w świadomości ludzi, którzy wydają się czasami bezwolnymi jej uczestnikami. Przywołuje to w pamięci raporty Klubu Rzymskiego, a nade wszystko ten o „luce ludzkiej”, który już w latach 80. alarmował, że czas, w którym żyjemy, wymyka 
się człowiekowi, że stajemy się bezbronni wobec siły przemian kreowanej myślą ludzką, aczkolwiek bez antycypowania perspektywy dla dalszego życia (Botkin, Elmandjra, Malitza 1982). To trochę tak, jakbyśmy „tańczyli”, będąc odurzeni przyjemnością, a nie myśleli, że wraz z tym lotem kończy się dobro, może dalsze trwanie, życie. Alarmują dziś politycy społeczni, ekolodzy, demografowie, kulturoznawcy, a nawet ekonomiści, ale ci, którzy nie zatracili do końca humanizmu w swym ekonomicznym myśleniu i postrzeganiu świata (Wieruszewska 2012, s. 145). Pośród tych głosów słychać ciągle słabo nauczycieli, pedagogów. Nie chodzi mi tutaj o ich protesty w odniesieniu do warunków finansowych wykonywanego zawodu oraz przywilejów z racji jego wykonywania. Nie zamierzam w tym miejscu wejść w dyskusję, czy te protesty są zdecydowanie uzasadnione, słuszne, czy budzą w szerszym odbiorze społecznym wątpliwości ${ }^{1}$. Mnie chodzi o głos nauczycieli w kierunku rozumienia i asymilowania koniecznej zmiany społecznej, cywilizacyjnej, która wymusza na edukacji, a zatem w samych nauczycielach konieczność ich otwarcia się na asymilowanie nieuchronnego „nowego”. Jeśli stan nauczycielski w tym kierunku nie podąży, nie uczyni $z$ "nowego" głównej siły napędowej $\mathrm{w}$ ewoluowaniu edukacji, to ta pozostanie daleko w tyle współczesnych potrzeb cywilizacji, a jej uprzywilejowane miejsce przejmą wyłącznie żywo reagujące społeczne źródła informacji medialnej/elektronicznej (Andrzejewska, Bednarek, Bożejewicz, Chaberska 2008, s. 11-24). Problem jednak w tym, że te współczesne i ekspansywne źródła informacji są aksjologicznie obojętne. Smutna więc przed nami perspektywa - cywilizacji nasyconej informacją, ale bez rozeznania dobra i zła. Ryzyko wydaje się oczywiste.

By dalej zmierzać w kierunku refleksji nad poszukiwaniem optymalnego modelu współczesnego nauczyciela, nade wszystko polskiego, bo ten mi najbliższy, choć w odniesieniach europejskich i światowych przeze mnie postrzegany, to zamierzam w dalszej części niniejszego opracowania poczynić refleksje nad ważnymi w moim przekonaniu zjawiskami i procesami przemian cywilizacyjnych, które napotykamy w codziennym życiu. Jako takie postrzegam: przemieszczanie się transgraniczne społeczeństw o zróżnicowanej proweniencji wyznaniowej i kulturowej oraz zmierzanie współczesnej cywilizacji w kierunku likwidowania nierównego traktowania ludzi i zbiorowości społecznych ze względu na cechy psychosomatyczne, zakorzenienie $\mathrm{w}$ wierze i kulturze. Jako odbiorca i uczestnik żywo dziejącej się rzeczywistości, znamionowanej licznymi nowymi zjawiskami, kształtowanej na drodze specyficznych procesów transformacyjnych, chcę włączyć się w dyskurs nad potrzebami zmian we współczesnej oświacie z polskiej perspektywy. Jest ona dla mnie kluczowa ze względu na troskę o wychowanie przyszłych

\footnotetext{
${ }^{1}$ Chodzi o ostatni ogólnopolski strajk nauczycieli, na wiosnę 2019 roku.
} 
pokoleń Polaków. Właściwe to stanowisku świadomego i zaangażowanego pedagoga (Smolińska-Theiss 2018, s. 11-12). Wyczuwam podobnie jak Elżbieta Górnikowska-Zwolak, reprezentująca pedagogikę społeczną, brak zaangażowania współczesnych pedagogów w sprawy społecznych przemian i wolę zachowania bezpiecznego dystansu wobec wyzwań współczesności (Górnikowska-Zwolak 2009, s. 347). To usytuowanie w zdystansowaniu od głównego nurtu przemian społecznych nie czyni ani polskiej pedagogiki, ani polskich pedagogów, nauczycieli, wychowawców, a nade wszystko polskich uczennic i uczniów, bezpiecznymi. Zaangażowanie w polskiej pedagogice postrzegam jako nakaz sumienia i aksjologiczny fundament, na którym należy budować aktualny wzorzec polskiego, nowoczesnego na miarę potrzeb i wyzwań nauczyciela (Pilch 1999, s. 33). Przekłada się on bezwzględnie na pragmatykę nauczania i wychowania opartą na etyczno-moralnych przesłankach realizowanego poprzez zadania edukacyjne zawodu. Chodzi zatem o nauczyciela-wychowawcę, reprezentującego postawy społecznego zaangażowania w sprawy aktualne, ważne dla życia i działania we współczesnym, złożonym świecie. Są one przeciwieństwem nihilizmu i konformizmu edukacyjnego, który uważam za poważną zaporę przed rozwojem pokoleń i w procesie społeczno-kulturowej ewolucji.

\section{STRUKTURALNA TEORIA POSTAW NAUCZYCIELSKICH}

Pomimo bogatej literatury dotyczącej postaw społecznych uważam, że wciąż w niedostatku pozostaje uprawiana nad nimi refleksja. Dotyczy to także środowisk pedagogicznych. Skoro ci, którzy odpowiadają za systematyczne i systemowo uprawnione wpływy społeczne - pedagodzy, nauczyciele, wychowawcy, edukatorzy - nie pogłębiają refleksji nad postawami społecznymi, a są przecież $\mathrm{z}$ wykonywanego zawodu powołującymi je $\mathrm{z}$ racji posiadanych uprawnień animatorami, to jak ma wyglądać współczesna przestrzeń relacji społecznie zróżnicowanych, wielokulturowych w trzecim tysiącleciu (Porożyński 2006, s. 364-369)?! Wyrażam tę obawę nie tylko jako teoretyk, ale także, a może przede wszystkim, jako praktyk i wrażliwy obserwator oraz uczestnik procesów społecznych. Przez wiele lat kształciłem nauczycieli czynnych zawodowo w ramach form kształcenia ustawicznego i doskonalenia zawodowego na studiach podyplomowych oraz kursach kwalifikacyjnych i doskonalących. Zaobserwowałem niebezpieczną właściwość ich myślenia o praktycznej pedagogice i zapewne powiązanego z tym myśleniem działania. Otóż, akcent w doskonaleniu zawodowym zdecydowanie pada na profesjonalizm merytoryczny i metodyczne umiejętności przekazu wiedzy. Niewiele osób chce się zastanawiać nad ideą relacji nauczyciel - uczeń, 
mało kto przejęty bywa w pracy pedagogicznej kategorią prawdy. Odbieram tę edukacyjną rzeczywistość jako w pewnym sensie nienaturalną, bo przecież prawdziwe życie, przeżywane uczucia i pragnienia odbywają się nieco poza nią. Efektem tego jest brak rozumienia postaw społecznych u współczesnych edukatorów, którzy w mojej ocenie raczej utożsamiają tę aktywność z przekazywaniem wiedzy, a nie zintegrowaną, wspólną przestrzenią okazywania siebie uczniom i bycia za sprawą tego wiarygodnym, autentycznym, po ludzku prawdziwym. Trudno do końca orzec, dlaczego tak się dzieje. Myślę, że samych nauczycieli nie należy ostatecznie za tę jakość winić. Stała się przecież ona formułą uprawianą przez Ministerstwo Edukacji Narodowej, w którym od wielu lat góruje ilość nad jakością. I przewrotnie nieco napiszę, nie ma to zbyt wiele wspólnego $\mathrm{z}$ heglowską dialektyką ducha rozumianą jako droga doskonalenia jakości (Rosiak 2011, s. 19). Edukacja, która stała się integralnym elementem polityki, wypracowała na szczeblu zarządczym mechanizmy i narzędzia selekcji, które ułatwiają przede wszystkim realizację politycznych założeń systemu oświaty. Zmarginalizowano misję edukacji, która poprzez prawdę świadczoną człowiekowi powinna być wolna od układów konformistycznych, interesów środowisk wybranych czy uprzywilejowanych i w najlepszym rozumieniu powinna służyć kształtowaniu tożsamości głęboko świadomych podmiotów według personalistycznie przyjmowanego celu i sposobu wychowania. Dzieje się tak, choć oficjalne głosy urzędnicze i aktualne trendy w reformowaniu oświaty zdają się temu przeczyć. Mnoży się więc dzisiaj, poprzez selektywne procedury, wymagania stawiane nauczycielom, które każą im gromadzić dyplomy, zaświadczenia, uprawnienia. Rekordziści nie dopinają własnych teczek personalno-kadrowych z powodu ich objętości, a jednocześnie wydają się bardzo zagubieni w relacjach $\mathrm{z}$ drugim człowiekiem. W celu egzemplifikacji chcę się posłużyć przykładem ostatniego strajku nauczycieli, skądinąd zrozumiałego $\mathrm{w}$ wielu postulatach spauperyzowanego środowiska zawodowego (Kim-Czapliński 2019, s. 18-21). Słuszność protestu, bez względu na to, kto jak o nim orzekał, nie uchroniła przed bolesnym skonfliktowaniem protestujących nauczycieli z rodzicami i uczniami. I nie jest to moim zdaniem jedynie sprawa politycznej manipulacji, a dowód na słabe kompetencje społeczne edukatorów, skutkujące nieumiejętnością porozumiewania się z szeroko rozumianym środowiskiem uczniowsko-rodzicielskim. Kluczem do zrozumienia tych problemów jest dla mnie właśnie kategoria postawy społecznej, która w esencjalnym znaczeniu pozwala zrozumieć siebie i własne relacje $\mathrm{z}$ innymi w odniesieniu do idei humanus (Kalman 1996, s. 146-147). Ta przecież, tak w życiu ludzkim, społecznym, jak i w procesie wychowania, okazuje się w ostateczności najważniejsza. Z pomocą dla tego zrozumienia misji edukacyjnej przychodzi znana wszak, ale niedoceniana i słabo rozeznana przez nauczycieli, strukturalna teoria 
postaw (Marody 1976, s. 15-22). Dużo o niej w opracowaniach psychologicznych i socjologicznych, co jednak nie przekłada się na praktykę relacji społecznych, a co gorsza tych edukacyjnych. Jak wspomniałem, merytoryka, a zatem wiedza, stan jej posiadania, lecz już niekoniecznie w odniesieniu aksjologicznym, jest dla nauczycieli najważniejsza. Przecież z tego ich rozliczają wraz z oceną ich poprawności systemowej. Brakuje nauczycielskiego zwrócenia się w kierunku uczuć, emocji i podejmowania działań ze świadomością i dobrze rozpoznaną motywacją oraz podejmowania na ich podstawie własnych decyzji. To przecież klasyczna triada pełnych postaw społecznych, których znaczenie w życiu człowieka bezspornie dyskutują psycholodzy humaniści, socjolodzy, szeroko postrzegają personaliści, a i filozofowie (Piłat-Borcuch 2013, s. 325-326). Trzy jej komponenty niezbywalne i w pełni zintegrowane to: wiedza, uczucia i działanie (Fidelus 2011, s. 97). Współcześni nauczyciele koncentrują się jednak na wiedzy. Z tej są przede wszystkim rozliczani. Próbują blokować w sobie uczucia, często tłumacząc to koniecznością zachowania profesjonalizmu w pracy edukacyjnej i rodzinną właściwością stanów emocjonalnych oraz rodzinną powinnością starań w tym zakresie. W ten sposób zamknięci we własnej wrażliwości, oddalają się od uczniów, depersonalizują się i instytucjonalizują w relacji z nimi, a relacje te stają się raczej rekwizytowe niż podmiotowo ludzkie. Stają się więc dla uczniów mało wiarygodni, bo dalecy. Wreszcie działanie, ale ujęte w przestrzeni zawodowej poprawności i konieczności wymagań, pozbawione jest tak koniecznej spontaniczności, autentyczności, prawdziwości, wynikającej z nieprzewidywalności ludzkich, codziennych sytuacji życiowych i wychowawczych. Wszystko musi być zaplanowane, obliczone, wymierzone. Doskonale wpisuje się w to zjawisko „zniewolenia” ramami programowymi, które w akademickiej rzeczywistości doszło do absurdu, odciągając nauczycieli od filozoficznego dyskursu wolnej myśli na sokratejski wzorzec (Jodłowska 2012, s. 175-202). Przekonany jestem, że we współczesnej edukacji zawodowej nauczycieli, wychowawców, pedagogów, należy powrócić do wolnej i twórczej myśli. Ta rodzi się w dyskusji, swobodnej wymianie poglądów i głęboko przeżyta w działaniu decyzyjnym stanowi podstawę edukacji podmiotów, a nie konstruowania robotów. Nauczyciel na miarę i potrzeby współczesnego wychowania wie, przeżywa stan własnej wiedzy i podejmuje świadomie decyzje, za które względem ucznia i własnej z nim relacji ponosi odpowiedzialność. Poprzestawanie jedynie na wiedzy i związanym z nią profesjonalizmie merytorycznym czyni nauczycieli bezwolnymi instrumentami stechnicyzowanej przestrzeni społeczeństwa informacyjnego (Nowak-Łojewska 2011, s. 173-186). 


\section{TRANSGRANICZNOŚĆ A EWOLUOWANIE POSTAW NAUCZYCIELSKICH}

Transgraniczność jest dzisiaj faktem i mamy dla jego potwierdzenia dowody w postaci licznych wydarzeń powodowanych przez wędrujące grupy ludności arabskiej, w tym syryjskiej, gnanej w nieznany świat wojną wywołaną brakiem odpowiedzialności polityków reprezentujących różne środowiska interesów, bądź fanatyków religijnych, sprowadzających w XXI wieku na powrót stare i znane mechanizmy dyskryminacji i represji. Napływa do nas także spora część ludności ze Wschodu, w tym z Ukrainy i innych krajów byłego Związku Radzieckiego. Ci ludzie, w poszukiwaniu lepszego jutra dla siebie i własnych rodzin, $\mathrm{z}$ tęsknoty za niezbywalnymi prawami człowieka do godnego życia, w tym i godziwej pracy, w nadziei przybywają do Polski. Wraz z nimi przekraczają granice naszego kraju ich problemy oraz cechy i to nie tylko te oczywiste, powiązane z potrzebami bytowymi, socjalnymi. Poprzez tych imigrantów w sposób na taką skalę wcześniej nieznany zyskujemy nowe elementy codziennej kultury społecznej, religijności czy też wyznaniowości i zwykłej codziennej obyczajowości. Rzecz w tym, że nie zawsze są one przez nas akceptowane i $z$ trudem asymilowane. W odwołaniu do wiary i tradycji upatrujemy w nich zagrożenia cywilizacyjne dla polskiej racji stanu, polskiej tożsamości i narodowej odrębności. Na tym tle rodzą się konflikty społeczne, pojawiają się nastroje nacjonalistyczne, będące bezpośrednim zagrożeniem dla tzw. innych. Zauważam, że ksenofobiczne nastawienia niektórych środowisk Polaków do napływającej obcej kulturowo i cywilizacyjnie ludności stają się zagrożeniem także dla nas samych (Gawron 2016, s. 134-141). Nieracjonalnie broniąc się przed nieuchronnymi w skali Europy i świata współczesnymi „wędrówkami ludów”, coraz bardziej odchodzimy od głównego nurtu życia współczesnej nam wielokulturowej cywilizacji, zamykając się w „kokonie” własnych strachów i fobii. Nie ma możliwości zachowania we współczesnym świecie czystości ras, narodów i kultur. Możemy jedynie za sprawą politycznie powodowanych narzędzi spowalniać ów proces mieszania się społeczności świata. Ale to nas nie chroni, nie daje nam tak koniecznych nowych sposobów asymilowania różnic oraz wywołuje groźne napięcia, które mogą przeradzać się z czasem w zjawiska ekskluzji, dyskryminacji i, oby nigdy, eksterminacji. Zamykamy się też na rozwój, bo przecież siłą napędową każdego rozwoju jest „nowe”, to, co nieznane, a co bywa wyzwaniem dla poznawania i poszukiwania dróg rozumienia. Sprzyjamy w ten sposób nie tylko postawom nacjonalistycznym i zachowaniom ksenofobicznym, ale także budujemy najlepszy grunt dla konformizmu, uniformizmu. Całkiem realne stają się $\mathrm{w}$ perspektywie mechanizmy społecznej selekcji, znane nam i historycznie 
boleśnie wspominane ${ }^{2}$. Uważam, że nastał obecnie czas nieuchronny dla takiego kształtowania postaw społecznych nauczycieli i wychowawców oraz takiego kształtowania ich sylwetek zawodowych, by podejmując się zadań edukacyjnych czuli się bezpiecznie w zróżnicowanej kulturowo rzeczywistości, by umieli ją mentalnie rozpoznawać, doświadczać i poruszać się w niej zgodnie z najwyższym nakazem, jakim jest dobro każdego człowieka, bez względu na rasę, wyznanie, poglądy polityczne, zakorzenienie w kulturze (Szkudlarek 2003, s. 415-424). Dlatego też będąc od wielu lat nauczycielem akademickim kształcącym pedagogów, zauważam, że zbyt mało jest $\mathrm{w}$ akademickiej edukacji treści przybliżających przyszłym edukatorom różne rasy, narody i kultury. Sama pedagogika porównawcza jako przedmiot ogólnego bloku kształcenia pedagogów ciągle zanadto skupia się na szczegółowych rozwiązaniach systemów edukacyjnych państw Europy i świata $\mathrm{w}$ aspekcie merytoryczno-metodycznym oraz organizacji i zrządzania oświatą, a nie prowadzi w refleksji ku zrozumieniu ideałów wychowania przyjmowanych przez różne państwa i zamieszkujące je narody. To drugie ogranicza się do dość ogólnych refleksji i postulatów (Nowakowska-Siuta 2014). A przecież ideały te respektują uwarunkowania wyznaniowe, kulturowe, historyczne, a nawet geopolityczne. Zatem w próbie rozumienia „innego” potrzebujemy wiedzy o innym człowieku, postrzeganym holistycznie i hermeneutycznie. To ważniejsza wiedza od tej, czy akurat w tym roku w takim lub innym państwie na świecie dzieci rozpoczynają obowiązek szkolny od szóstego czy siódmego roku życia. Tym bardziej, że szczegółowe rozwiązania systemowo-edukacyjne ciągle się zmieniają i nie są wolne od programów politycznych rządzących partii. Mając na względzie powyższe, warto odwołać się do manifestu psychologów-humanistów, którzy w przemyśleniu i opracowaniu Jamesa Fredericka Bugentala wskazali na podstawy podmiotowej siły człowieka i koniecznej społecznej integracji. Rozpocząć trzeba od stwierdzenia, że człowiek nie jest złożeniem prostych elementów, a zawsze należy go postrzegać jako całość psychosomatyczną. Zatem nie można człowieka widzieć jedynie poprzez jego inność, ale należy starać się zrozumieć różne konteksty i przyczyny tej inności. Zrozumienie jest kluczem do budowania zgody i współpracy. Dla człowieka jest ważny tak zwany ludzki kontekst, co oznacza, że tyle siebie poznamy i zrozumiemy, na ile pozwoli nam relacja $\mathrm{z}$ drugim, $\mathrm{z}$ innym człowiekiem. Zatem, zamykanie się na Innego prowadzi do zubożenia siebie samego, blokuje nas w rozwoju. Poza tym człowiek jest bytem świadomym aż po kres własnej świadomości, świadomym aż do nieświadomości. W tej konstatacji wyraża się filozoficzne „wiem, że nic nie wiem” i sokratejska heureza prowadząca nas ku niedostrzeganym do końca, aczkolwiek koniecznym i możliwym etapom naszego rozwoju. Dlatego właśnie

${ }^{2}$ Odwołanie do doświadczeń holocaustu. 
należy się otwierać na tych, których nie znamy, nie rozumiemy. Z tej niewiedzy i woli poznania powinniśmy uczynić podstawę dla naszego podmiotowego rozwoju, który przecież wzbogaci też życie społeczne pełne różnic początkowo niepojętych, a później zasymilowanych i także nas wzbogacających. I wreszcie człowiek jest bytem intencjonalnym, zmierzającym w działaniu do uświadomionego celu (Rosińska, Matusewicz 1987, s. 241-251). W odniesieniu do Innego ważne jest owo uświadomienie sobie celu i skutków naszych zachowań, naszej aktywności. By uczynić cel racjonalnym, roztropnym oraz podmiotowo i społecznie optymalnym, trzeba najpierw Innego poznać i starać się go w różnych kontekstach zrozumieć oraz zaakceptować jego prawo do inności, do różnicy względem nas dostrzeganej. Na zakończenie niniejszego wątku chciałbym jeszcze zwrócić uwagę na triadę znamionującą społeczny charakter Ja podmiotowego, w której jest ono jednym $\mathrm{z}$ trzech fundamentów człowieczeństwa $\mathrm{w}$ humanistycznych kategoriach pojmowanego. Dwa pozostałe to Drugi lub Inny oraz „spotkanie”, które otwiera Ja na Innego dając człowiekowi-podmiotowi poprzez zrozumienie i zaakceptowanie Drugiego poczucie własnej wolności w otwartości oraz szansę na pełny rozwój tak podmiotowy, jak i społeczny (Rosińska, Matusewicz 1987, s. 250).

W kształtowaniu postaw społecznych i sylwetek zawodowych należy zatem umieszczać przyszłych edukatorów zarówno w przestrzeni wiedzy, jak i umiejętności, a także kompetencji. Parafrazując to w kierunku strukturalnej teorii postaw - w obszarze wiedzy, emocji (uczuć) i działań świadomych (Pankowska 2016, s. 191-194). To wszystko w kształceniu akademickim nauczycieli i wychowawców ma ich otwierać na poznawanie i budowanie wspólnoty życiowej z Drugim, Innym i różnym od nas człowiekiem. Argument ten jest nie do odparcia, a przemawiają za nim coraz bardziej liczne przypadki obecności dzieci i młodzieży z innych kultur, wyznań, ras, pośród zespołów edukacyjnych przedszkolnych i szkolnych. To jednoznacznie przemawia za przygotowaniem pedagogów do pracy $\mathrm{w}$ tak zróżnicowanych pod względem wielu cech zespołach edukacyjnych.

\section{IDEA RÓWNEGO TRAKTOWANIA A EWOLUOWANIE POSTAW NAUCZYCIELSKICH}

Migracje ludności, ale nie tylko one, bo i naturalne przyczyny różnicowania się środowisk społecznych, powodują, że zespoły uczniowskie bywają dzisiaj niejednolite. Ta niejednolitość dotyczy jak zawsze cech społecznych i podmiotowych, a są nimi: pochodzenie społeczne, stan zamożności, czy też uposażenia socjalno-bytowego rodzin uczennic i uczniów, poziom świadomości i intelektualnej kondycji rodziców uczących się dzieci, stan kultury, w tym pedagogicznej w rodzinach, konstytucja 
zdrowotna, psychofizyczna dzieci szkolnych z szczególnym uwzględnieniem pełnej sprawności psychofizycznej i niepełnosprawności oraz wiele innych. Do tych cech aktualnie doszły wcześniej rzadko występujące, a dziś coraz bardziej powszechne, a związane z migracją ludności. Są nimi: rasa, wyznanie (religia), kultura w odniesieniu do głównych kierunków rozwoju cywilizacji na świecie, ale też te, które są skutkiem powszechnie dostrzeganej konieczności tolerancji i równego traktowania, jak: nowe zjawiska w zakresie płciowości człowieka wraz z reinterpretowaniem i redefiniowaniem płci w ogóle, orientacja seksualna (Paprzycka, Mianowska, Izdebski 2016, s. 105-108). Nie chcę niniejszym opracowaniem wpisywać się w aktualny w Polsce spór prowadzony wokół edukacji seksualnej, bo nie to jest jego celem, ale wypada jasno stwierdzić, że podane cechy podmiotowe i społeczne, a odnoszone do seksualności człowieka są faktem i temu faktowi przeczyć się nie da. Seksualność, czy też płciowość, człowieka ewoluuje jak wszystko co dotyczy życia ludzkiego w przestrzeni naturalnej i społeczno-kulturowej. Zauważam w tej ewolucji w pełni uprawniony proces zmian, który jest siłą niezależną od woli tych czy innych środowisk lobbystycznych o ściśle określonych poglądach związanych z konkretną i utrwaloną, a może „utwardzoną”, opcją światopoglądową. Ewolucja człowieka i zbiorowości ludzkich wskazuje, moim zdaniem, na nieuchronną determinację ze strony trzech „filarów” życia podmiotowego i społecznego. Są nimi: bios, ethos i los (Sarnat-Ciastko 2011, s. 225-230). Biologicznie się zmieniamy, co jest naukowo stwierdzonym faktem. Na przykład jesteśmy wyżsi i wydłuża się nam wiek życia. Jednocześnie spada zdolność prokreacyjna gatunku ludzkiego jak wskazują badania, wynikająca ze stosowania pestycydów i wszelakiej chemii jako środka ochrony upraw (Bojanowska, Kostecka 2018, s. 425-428; Witczak, Pohoryło 2016, s. 503-512). Wartości rozumiane jako ethos ulegają współcześnie zaskakującym interpretacjom, które pomimo szokowania trwają w kulturze współczesnych społeczeństw. I tu przykładem może być stosunek do samobójców lub kobiet, które decydują się urodzić dziecko poza układem konkubenckim lub małżeńskim. Nieszczęśliwi samobójcy dzisiaj a grzesznicy pozbawiający się życia wbrew woli Boga niegdyś, warci jedynie pochówku „pod płotem” cmentarnym; kobiety-bohaterki podejmujące trud samodzielnego wychowania dziecka dzisiaj a panny z bękartem niegdyś - to tylko niektóre przykłady reinterpretacji zjawisk społecznych. Zatem zmiana wpisana jest w cywilizację jako jej cecha konstytutywna, a wszelka stałość o tyle obowiązuje, o ile wyraża się poprzez asymilację tej zmiany, stałość sama w sobie jest ciągle obecnym prawem do zmiany (Szempruch 2012, s. 11-158). Można tu przywołać stanowisko papieża Franciszka, który będąc a priori jako głowa Kościoła powszechnego obrońcą wszelkiej stałości wiązanej z Bogiem jako stałością i wiecznością doskonałą, jednocześnie wypowiedział owe znamienne słowa w odniesieniu do osób homoseksualnych, które poddały w wątpliwość jego 
podmiotowość krytyczną jako osoby ludzkiej oraz jego teologalną misję hierarchy jako uprawnionego do oceny tychże osób ${ }^{3}$. Nie ma w moim przekonaniu żadnego argumentu biblijnie i ewangelicznie możliwego do obrony, który wykluczałby jakiekolwiek osoby z rodzaju ludzkiego ze względu na ich cechy społeczne czy biologiczne, podmiotowe, zarówno te wrodzone, jak i w ciągu życia nabywane. Są za to argumenty przemawiające za równością w akceptacji każdego człowieka i tolerancją regulującą relacje międzyludzkie (Wójcik 2018, s. 63-65). Najlepszym tego przykładem, wręcz doskonałym paradygmatem biblijnym, jest Mesjasz i jego miłość wszechogarniająca wszystkie Boże stworzenie bez wyjątku, zarówno to miłe Bogu ze względu na czystość ewangelicznie rozumianą, jak i to grzeszne (Lubelski 1913). Nie da się zatem w odniesieniu do tak przywoływanej argumentacji odnaleźć jakiejkolwiek uprawnionej podstawy do wykluczania społecznego ze względu na różnice i to bez znaczenia, czego dotyczą. $Z$ takich właśnie powodów współczesny nauczyciel-wychowawca musi być otwarty na różnice występujące w zespołach edukacyjnych. Powinien te różnice asymilować jako organizator i realizator celów edukacyjnych, ale i czynić z nich podstawę dla wyprowadzania celów edukacyjnych w odniesieniu do zmieniającej rzeczywistości społecznej, organizmu na wskroś fenomenalnego ze względu na proces jego ewolucji (Zielińska 2016, s. 229-230). Z satysfakcją mogę stwierdzić, że w edukacji polskiej, zgodnie ze standardami europejskimi, wiele się dzieje na rzecz wyrównywania szans, tolerancji i inkluzyjnego traktowania dzieci ze względu na występujące pomiędzy nimi różnice podmiotowe i społeczne. Najlepszym tego przykładem jest integracja dzieci z normą rozwojową $\mathrm{z}$ tymi, które $\mathrm{w}$ rozumieniu biomedycznym tej normy nie osiągają (Speck 2005, s. 70-71). Pamiętamy jednak całkiem niedawną selekcję dzieci i młodzieży, warunkowaną ekonomicznie, kiedy powstające na gruncie legislacji ustawy oświatowej 1991 roku szkoły prywatne zyskały niechlubne miano szkół elitarnych ze względu na edukowanie dziewcząt i chłopców z tak zwanych dobrych domów, pod którą to nazwą ukryta była zasobność portfela rodziców (Królikowska 2012, s. 51-54). Z latami dopiero szkoły te zaczęły się profilować według zainteresowań i talentów uczniów, a fatalnie pojęta elitarność została zastąpiona profesjonalizacją ze względu na rozszerzane czy wprowadzane nowe kierunki edukowania $\mathrm{z}$ racji przeznaczenia zawodowego, czy sztuki i kultury. Jedynym kryterium podziału dzieci i młodzieży w przestrzeni edukacyjnej powinny być zainteresowania własne, uzdolnienia, wszelkie usposobienia skutkujące specjalnymi predyspozycjami do kształcenia profilowego (Giza 2016, s. 13-25; Lejzerowicz 2016, s. 157-172). Ta ciągle jeszcze oczekiwana rzeczywistość szkol-

${ }^{3}$ Chodzi o słowa papieża Franciszka wypowiedziane w 2014 roku: „Jeśli ktoś jest homoseksualistą i z dobrą wolą poszukuje Boga, kimże jestem, by go oceniać." 
na wydaje się być na dobrej drodze zmian, a ekonomicznie pojmowane różnice pomiędzy edukacją publiczną i niepubliczną zdają się schodzić na dalszy plan, coraz bardziej tracą na znaczeniu w stosunku do optymalnych warunków rozwoju uczennic i uczniów. Mamy zatem do czynienia z nową interpretacją edukacji elit i edukacji masowej. Ten kierunek zmian wymaga przeobrażeń przekonań i postaw nauczycielskich. Nauczycielki i nauczycieli współcześnie ma wyróżniać nie to, kogo nauczają (choć nie jest to bez znaczenia w rozumieniu profesjonalizmu zawodowego) i z jakiego środowiska społecznego rekrutują się uczniowie, a sama misja edukacyjna o szczególnym znaczeniu w społecznej strukturze spełnianych ról i zadań. Traci więc znaczenie aspekt rekwizytowy edukacji, a zyskuje aspekt ideowy, etyczny spełnianej misji.

\section{PODSUMOWANIE}

Analizowana w niniejszym artykule potrzeba zmian w postawach społecznych nauczycieli, którym przychodzi się dzisiaj mierzyć z niebywale złożoną rzeczywistością edukacyjną, stanowi jeden z głównych problemów polskiej pedagogiki teoretycznej i praktycznej. Jeżeli współcześni nauczyciele nie podejmą trudu przebudowy postaw społecznych, to stagnacja oparta na rzemieślniczym profesjonalizmie nie pozwoli na skuteczne porozumiewanie się i oddziaływanie wychowawcze według potrzeb cywilizacji XXI wieku.

\section{LITERATURA}

Andrzejewska A., Bednarek J., Bożejewicz W., Chaberska A., 2008, Dziecko w sieci. Warszawa, Fundacja PEDAGOGIUM, Wyd. PEDAGOGIUM Wyższej Szkoły Pedagogiki Resocjalizacyjnej.

Barczyk P.P., 2003, Nauczyciel i oświata w kontekście integracji Europy. W: D. EkiertOldroyd (red.), Problemy wspólczesnej pedeutologii. Teoria - praktyka - perspektywy. Katowice, Uniwersytet Śląski, 143-157.

Bojanowska M., Kostecka M., 2018, Dieta i styl życia jako czynniki wpływające na płodność. „Kosmos. Problemy nauk biologicznych”, t. 67, nr 2, 425-439.

Botkin J.W., Elmandjra M., Malitza M., 1982, Uczyć się bez granic. Jak zewrzeć „lukę ludzkq"? Raport Klubu Rzymskiego. Warszawa, PWN.

Dereń E., 2014, Nowy paradygmat w kształceniu i doskonaleniu nauczycieli. Wałbrzych, Forum Inicjatyw Edukacyjnych i Obywatelskich. 
Dlaczego sobie nie ufamy. Szczęśliwy Polak zgrzyta zębami, 2019, (wywiad E. Kim z prof. J. Czapińskim o stanie polskiego nauczycielstwa i o strajku nauczycieli). „Neewsweek”, nr 16, 18-21.

Dziewulak D., 1997, Systemy szkolne Unii Europejskiej. Warszawa, Wydawnictwo „Żak”. Fidelus A., 2011, Postawy społeczne jako element kapitału społecznego a proces readaptacji społecznej skazanych. „Forum Pedagogiczne UKSW”, nr 1, 87-124.

Gawron M., 2016, Postawy ksenofobiczne wśród studentów wybranych kierunków studiów Krakowskiej Akademii im. Andrzeja Frycza Modrzewskiego. „Państwo i Społeczeństwo" (XVI), nr 1, 133-148.

Giza T., 2016, Zmiany w polityce oświatowej a jakość wsparcia dla uczniów zdolnych. „Państwo i Społeczeństwo” (XVI), nr 2, 13-25.

Górnikowska-Zwolak E., 2009, Myśl feministyczna jako nurt rozważań w pedagogice społecznej. Mysłowice, Wyd. Górnośląskiej Wyższej Szkoły Pedagogicznej im. Kardynała Augusta Hlonda w Mysłowicach.

Jodłowska B., 2012, Pedagogika sokratejska. Kraków, Oficyna Wydawnicza „Impuls”. Kalman Y., 1996, Martin Buber (1878-1965). W: C. Kupisiewicz, I. Wojnar (red.), Myśliciele - o wychowaniu. Warszawa, Polska Oficyna Wydawnicza BGW, 145-159. Królikowska I., 2012, „Nasza idealna szkoła” - o oczekiwaniach i partycypacji rodziców $w \dot{z} y c i u$ podstawowej szkoły prywatnej. „Colloquium Wydziału Nauk humanistycznych i Społecznych", nr 4, 51-74.

Lejzerowicz M., 2016, Indywidualizacja w działalności wychowawczej i dydaktycznej. „Studia z Teorii Wychowania”, t. VII, nr 3(16), 157-176.

Lubelski J. ks., 1913, Chrystus i grzesznicy. Tarnów, Księgarnia i drukarnia Zygmunta Jelenia.

Marody M., 1976, Sens teoretyczny a sens empiryczny pojęcia postawy. Analiza metodologiczna zasad doboru wskaźników w badaniach nad postawami. Warszawa, PWN.

Nowak-Łojewska A., 2011, Nauczyciel „konserwa” (?) - odporny na zmiane relikt $w$ skansenowej szkole. „Studia Pedagogiczne”, t. LXIV, 173-186.

Nowakowska-Siuta R., 2014, Pedagogika porównawcza. Problemy, stan badań i perspektywy rozwoju. Kraków, Impuls.

Pankowska D., 2016, Kompetencje nauczycielskie - próba syntezy (projekt autorski). „Lubelski Rocznik Pedagogiczny”, t. XXXV, z. 3, 187-209.

Paprzycka E., Mianowska E., Izdebski Z., 2016, Kobiecość i męskość Polaków. Społecznokulturowy wymiar ptci jako kategoria analityczna. „Rocznik Lubelski”, t. 42, cz. 1, 105-125.

Pilch T., 1999, Granice wolności i zaangażowania pedagogiki społecznej. W: E. Górnikowska-Zwolak, A. Radziewicz-Winnicki (red.), Pedagogika społeczna w Polsce - między stagnacją a zaangażowaniem. T. 1, Katowice, Wyd. Uniwersytetu Śląskiego, 30-39. 
Piłat-Borcuch M., 2013, Pomiędzy tożsamościq osobowa a postawa społeczna. „Zeszyty Naukowe Politechniki Śląskiej, Seria: Organizacja i Zarządzanie”, z. 65, 317-327. Porożyński H., 2006, Wielokulturowość wyzwaniem dla współczesnej polskiej edukacji. Stan i perspektywa badań. W: R. Grzybowski, T. Maliszewski (red.), W stużbie historii nauki, kultury i edukacji. Ksiega pamiątkowa dedykowana prof. Lechowi Mokrzyckiemu z okazji Jubileuszu pięćdziesięciolecia pracy zawodowej. Gdańsk, Wydawnictwo Uniwersytetu Gdańskiego, 364-369.

Rosiak M., 2011, Dialektyka Hegla. Krytyczny komentarz do głównych tekstów metafizycznych. Kraków, Towarzystwo Autorów i Wydawców Prac Naukowych UNIVERSITAS.

Sarnat-Ciastko A., 2011, Koncepcja dynamizmów rozwojowych Stefana Kunowskiego w optyce edukacyjnej analizy transakcyjnej. Częstochowa, Prace Naukowe Akademii im. Jana Długosza w Częstochowie. Seria: Pedagogika, z. 20, 221-231.

Smolińska-Theiss B., 2018, Pedagogika społeczna - pedagogika społecznie zaangażowana wokół inicjatyw i ruchów społecznych. „Pedagogika społeczna”, nr 4(70), 9-16.

Speck O., 2005, Niepełnosprawni w społeczeństwie. Podstawy ortopedagogiki. Gdańsk, Gdańskie Wydawnictwo Psychologiczne.

Suchocka A., Królikowska I., 2014, Kreowanie tożsamości kulturowej jako wyzwanie XXI wieku. „Colloquium Wydziału Nauk Humanistycznych i Społecznych AMW”, nr 4, 73-88.

Szempruch J., 2012, Nauczyciel w warunkach zmiany społecznej i edukacyjnej. Kraków, Oficyna Wydawnicza „Impuls”.

Szkudlarek T., 2003, Pedagogika międzykulturowa. W: Z. Kwieciński, B. Śliwerski (red.), Pedagogika. Podręcznik akademicki, t. 1, Warszawa, Wydawnictwo Naukowe PWN SA.

Wieruszewska M., 2012, Kultura - gospodarka. Przestrzeń dla humanistów. „Etnografia Polska”, t. 56, z. 1-2, 143-156.

Witczak A., Pohoryło A., 2016, Ocena zanieczyszczenia żywności pestycydami fosforoorganicznymi a ryzyko zdrowotne konsumentów. „Kosmos. Problemy nauk biologicznych", t. 65, nr 4, 503-512.

Wójcik M., 2018, Kobiecość niepełnosprawna w perspektywie prawa Bożego (luźne refleksje pedagoga nad wybranymi wątkami antropologii biblijnej). W: E. GórnoikowskaZwolak (red.), Kobiety z niepełnosprawnościa i wobec niepełnosprawności. Zagadnienia edukacji i socjalizacji. Katowice, Wydawnictwo Uniwersytetu Śląskiego, 61-76. Zielińska M., 2016, Tradycjonalista czy innowator? Nauczyciel wobec wyzwań współczesności. „Edukacja - Technika - Informatyka”, nr 3/17, 227-232. 
THE PEDAGOGUE'S REFLECTIONS

ON THE NEED TO NOTICE THE ETHICAL CONDITIONS OF THE CHANGES NECESSARY IN THE TEACHING ATTITUDES IN THE $21^{\text {ST }}$ CENTURY

PART I (FROM NATIONAL EDUCATION TO CROSS-BORDER EDUCATION OPEN TO EQUAL OPPORTUNITIES)

\begin{abstract}
In the article, the author attempts to analyze the contemporary conditions for the necessary changes in teachers' attitudes. He perceives the philosophical reflection in the direction of ethics as the basis for drawing conclusions on the optimal education and shaping and professional functioning of people responsible for the education of the young generation. In the reflectiveness of the educational environment, the author also perceives the chance to understand the ethical conditions of changes in the contemporary profiles of teachers, which are forced by new demographic and socio-cultural phenomena in Europe and in the world. The article is in line with the search for a thoroughly modern paradigm of personality of educators in the XXI century.
\end{abstract}

Keywords: ethics, teaching attitudes, civilisational transformations, cross-border migration, equality in education 